\title{
Influence of Two-Stage Anodization on Properties of the Oxide Coatings on the Ti-13Nb-13Zr Alloy
}

\author{
Agnieszka Ossowska ${ }^{1, *}$, Andrzej Zieliński ${ }^{1}{ }^{\circledR}$, Jean-Marc Olive ${ }^{2}$, Andrzej Wojtowicz ${ }^{3}$ and \\ Piotr Szweda 4 (D) \\ 1 Department of Materials Engineering and Bonding, Gdansk University of Technology, 80233 Gdańsk, \\ Poland; andrzej.zielinski@pg.edu.pl \\ 2 Institut de Mécanique et d'Ingénierie, Université de Bordeaux, 33405 Talence CEDEX, France; \\ jean-marc.olive@u-bordeaux.fr \\ 3 Department of Dental Surgery, Medical University of Warsaw, 02097 Warsaw, Poland; \\ awojt@kcs.amwaw.edu.pl \\ 4 Department of Pharmaceutical Technology and Biochemistry, Gdansk University of Technology, \\ 80233 Gdańsk, Poland; piotr.szweda@pg.edu.pl \\ * Correspondence: agnieszka.ossowska@pg.edu.pl; Tel.: +48-58-347-19-63
}

Received: 2 June 2020; Accepted: 20 July 2020; Published: 22 July 2020

\begin{abstract}
The increasing demand for titanium and its alloys used for implants results in the need for innovative surface treatments that may both increase corrosion resistance and biocompatibility and demonstrate antibacterial protection at no cytotoxicity. The purpose of this research was to characterize the effect of two-stage anodization-performed for $30 \mathrm{~min}$ in phosphoric acid-in the presence of hydrofluoric acid in the second stage. Scanning electron microscopy, atomic force microscopy, energy-dispersive X-ray spectroscopy, X-ray diffraction, Raman spectroscopy, glow discharge optical emission spectroscopy, nanoindentation and nano-scratch tests, potentiodynamic corrosion studies, and water contact angle measurements were performed to characterize microstructure, mechanical, chemical and physical properties. The biologic examinations were carried out to determine the cytotoxicity and antibacterial effects of oxide coatings. The research results demonstrate that two-stage oxidation affects several features and, in particular, improves mechanical and chemical behavior. The processes influencing the formation and properties of the oxide coating are discussed.
\end{abstract}

Keywords: titanium alloys; electrochemical oxidation; nanotubular oxide layers; microstructure; nanomechanical properties; corrosion resistance; wettability; antibacterial protection; cytotoxicity

\section{Introduction}

Titanium and its alloys - due to their mechanical properties-excellent corrosion resistance, and a high strength/density ratio, are nowadays the most appropriate materials for load-bearing implants and biomedical materials [1,2] used, e.g., in arthroplasty [2,3], as dental implants [4-6] and dental prostheses [7]. The titanium and its alloys proposed for medicine, after their oxidation, include medical titanium [8-10], Ti-6Al-4V [11,12], Ti-6Al-7Nb and Ti-13Nb-13Zr [13] alloys. The most commonly used Ti-6Al-4V alloy contains alloying elements, which may provoke undesirable tissue reactions damaging nerves cells, softening the bones, and, as a consequence, resulting in the appearance of diseases of the circulatory and central nervous systems [14,15]. Therefore, Ti-13Zr-13Nb alloy was chosen for this research as it has no harmful elements and possesses a low (76 GPa) Young's modulus, similar to that of cortical bone, providing better stress distribution at the implant-bone contact zone and preventing against loosening and damage of the implant.

The different surface modification methods of titanium alloys such as deposition of coatings, oxidation, ion beam surface modification, ion implantation, titanium plasma spraying, acid etching, 
grits blasting, sandblasting followed by acidic etching, electropolishing and laser melting were applied for titanium and its alloys for biomedical applications [16]. In particular, adhesion of the cells has been shown better on rough than on smooth surface $[17,18]$. Such surface characteristics may be achieved by the laser treatment $[19,20]$, surface mechanical attrition [21,22], acid etching [23,24], deposition of phosphate [25-29] and composite coatings [30-32]. Among those modifying approaches, the oxidation remains essential as it can either form nanotubular oxide structures or rough oxide surfaces, enhancing the adhesion of osteoblasts, if alone, and deposition of coatings, if used as an interlayer.

Oxidation plays an essential role among possible surface engineering methods, and even a spontaneously formed titanium oxide layer is a barrier limiting the entry of metal ions into tissues [33]. Moreover, the oxide layer may influence the osteoinduction processes by a change in the architectural features and chemical composition of the oxides [34]. The techniques used for this purpose include the low voltage anodization, micro-arc oxidation (MAO) [35], thermal oxidation of titanium biomaterials [36], less often the oxidation using hydrogen peroxide [37] and laser-enhanced oxidation [38].

The MAO is used as a technique for creating a multiporous or highly developed surface, often implemented with different ions [39-42]. A novel "cortex-like" micro/nano dual-scale structured $\mathrm{TiO}_{2}$ coating was prepared in such a way in tetraborate electrolytes [43]. The MAO in ammonium acetate was resulted in a multiporous, crystalline titanium oxide layer demonstrating the apatite forming ability [9]. The antibacterial activity may be achieved by the MAO performed in electrolytes comprising $\mathrm{Ag}$, $\mathrm{Cu}$ or $\mathrm{Zn}[40]$. However, this technique needs a high voltage and results in thick oxide coatings.

The low potential electrochemical oxidation may result in either the compact oxide [44] or nanotubular oxide coatings, depending on the type of electrolyte and anodization parameters [45-55]. The $\mathrm{TiO}_{2}$ nanotubular surface provided topography favorable for improving the clinical performance of implants when comparing to the sand-blasted acid-etched topography [56]. The individual nanotubes can be filled with antibiotics or nanometals for introducing the antibacterial ability. The release rate of nanosilver depends on its placement: relatively fast release was observed for nanoAg inside the nanotubes and gradual release, for Ag inside the cavities [57]. The functionalization of titanium dioxide nanotubes with some biomolecules was developed for biomedical applications [58] and the osteogenic differentiation can be modulated by various additional treatments of nanotube coatings on Ti-6Al-4V implants [12]. Superhydrophobic titanium oxide nanotube arrays may serve as the drug reservoir, and ultrasonic waves may trigger the drug release [59]. Such a superhydrophobic Ti surface was fabricated by subsequent anodization in $\mathrm{H}_{2} \mathrm{O}_{2}$ followed by aging [60]. Hierarchical structures were obtained, applying two nanotexturing surface treatments onto titanium coatings, anodic oxidation and alkaline treatments, and the simultaneous presence of micro-/nano-roughness resulted in a distinct increase in cell proliferation [61].

Different composite coatings were also developed. The ion implantation of helium ions was made on the oxide film obtained by previous anodization to improve hydrophilic properties [8]. The decoration of previous titanium oxide nanotubes with $\mathrm{MnO}$ increased the ability to form apatite [62]. Osseointegration was enhanced by coating the titanium implants with a nanostructured thin film comprised of titanium carbide and titanium oxides clustered around graphitic carbon [63].

The oxides obtained by low voltage anodization can be in the form of thin, compact coatings or nanotubular layers. In the past, the bi-layer coating was prepared [47] by gas oxidation of titanium alloy and then electrochemical oxidation resulting in nanotubular layers grown on the previous compact oxide layer. Such treatment brought out the highly corrosion-resistant coatings but possessing the relatively short nanotubes. Therefore, the present research has applied the two-stage electrochemical oxidation assuming that such procedure may positively affect some properties of the oxide coatings, in which the nanotubular layer is formed not in the bare metal, but in the compact oxide layer. In particular, the mechanical and chemical behavior have been expected to improve. 


\section{Materials and Methods}

The study was performed on a two-phase titanium alloy $\mathrm{Ti}-13 \mathrm{Nb}-13 \mathrm{Zr}$ of chemical composition listed in Table 1. The microstructure of the investigated alloy (Baoji SeaBird Metal Materials Co., Ltd., Baoji, China) is shown in Figure 1. It is a $\beta$-phase structure comprising of the $\alpha^{\prime}$ phase being a supersaturated solution with a slightly stubborn effect and a martensitic structure, which is formed as a result of rapid cooling from the temperature of the $\beta$-phase stability or as a result of plastic deformation.

Table 1. Chemical composition of the $\mathrm{Ti}-13 \mathrm{Nb}-13 \mathrm{Zr}$ alloy, weight percent (according to manufacturer's certificate).

\begin{tabular}{cccccccc}
\hline $\mathbf{N b}$ & $\mathbf{Z r}$ & $\mathbf{F e}$ & $\mathbf{C}$ & $\mathbf{N}$ & $\mathbf{H}$ & $\mathbf{O}$ & $\mathbf{T i}$ \\
\hline 13.5 & 13.5 & 0.05 & 0.04 & 0.013 & 0.004 & 0.11 & bal. \\
\hline
\end{tabular}

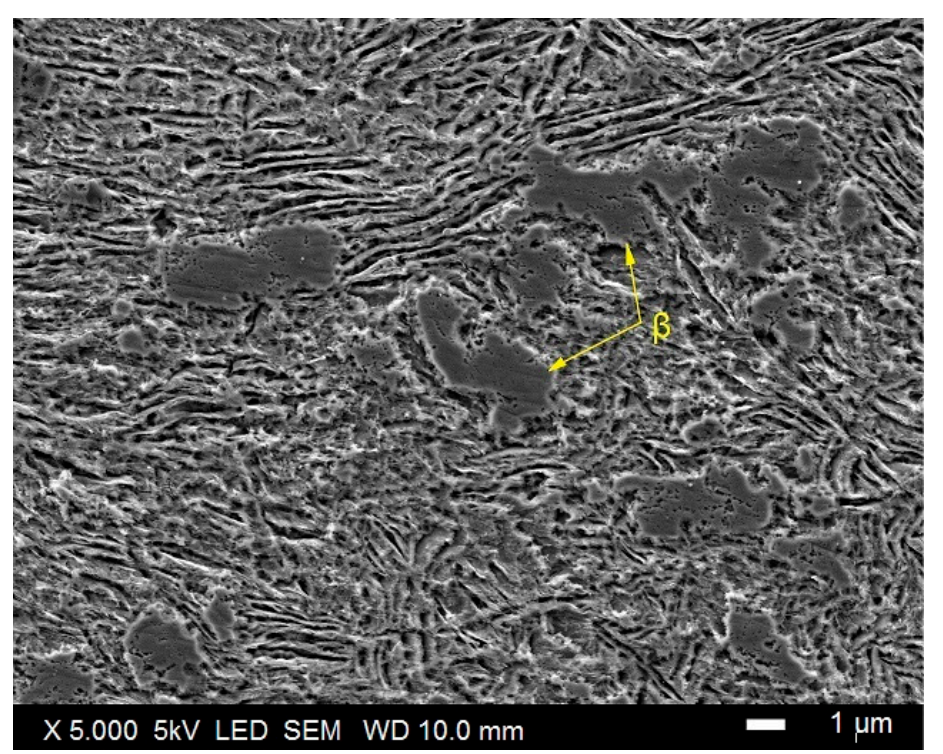

Figure 1. Microstructure of the Ti-13Nb-13Zr alloy after etching with the Kroll solution composed of $2 \mathrm{~mL} \mathrm{HF}$ (40 wt.\%), $2 \mathrm{~mL} \mathrm{HNO}_{3}\left(55\right.$ wt.\%) $+96 \mathrm{~mL} \mathrm{H}_{2} \mathrm{O}$.

The specimens of dimensions $15 \mathrm{~mm} \times 10 \mathrm{~mm} \times 4 \mathrm{~mm}$ were cut from the alloy sheet of initial thickness of $4.2 \mathrm{~mm}$. Then the samples were ground with abrasive papers (No. 2500 as the last, Struers, Inc., Cleveland, OH, USA). Afterward, the specimens were cleaned in an ultrasonic chamber (Sonic-2, Polsonic Palczynski Sp. J., Warsaw, Poland) with isopropanol, methanol (Avantor Performance Materials Poland S.A., Gliwice, Poland) and distilled water, subsequently, for $5 \mathrm{~min}$ in each batch and finally dried in cold air.

The tests were performed in a standard circuit composed of an electrochemical cell, power supply (SPN-110-1C, MPC Lab Electronics, Nijmegen, The Netherlands), Pt electrode as the polarizing electrode and the tested metallic electrode. Neither stirring, aeration nor deaeration were applied. All measurements were performed at room temperature. The anodization parameters were set up based on some earlier investigations [47]; in particular, even if the electrochemical oxidation time has a small effect on the oxide thickness, the $30 \mathrm{~min}$ period was assumed necessary to perform the electrochemical oxidation at equilibrium conditions.

The anodization was carried out at the first stage electrochemically in $1 \mathrm{M}$ orthophosphoric acid $\left(\mathrm{H}_{3} \mathrm{PO}_{4}\right)$ at the potential value of $40 \mathrm{~V}$, in one step, at $20^{\circ} \mathrm{C}$, for $30 \mathrm{~min}$ (samples obtained in such a way are here designated as EO1). The electrochemical oxidation was repeated in $1 \mathrm{M}$ orthophosphoric acid with an addition of $0.3 \mathrm{vol} . \%$ of hydrofluoric acid (HF) (designation EO2). The process was performed again at $20^{\circ} \mathrm{C}$, at a potential value of $20 \mathrm{~V}$, in one step, for $30 \mathrm{~min}$. The coatings were also obtained 
by two-stage oxidation-first EO1, then EO2 (designation EO1 + EO2). After each of the processes, the samples were rinsed in distilled water and dried in cold air. The samples were heat-treated after oxidation at $400{ }^{\circ} \mathrm{C}$ for $2 \mathrm{~h}$ in the air (humidity $<70 \%$ ).

The surfaces of specimens and their cross-sections after each form of oxidation were examined with the scanning electron microscope (SEM JEOL JSM-7600 F, JEOL, Ltd., Tokyo, Japan), equipped with a LED detector, at $5 \mathrm{kV}$ acceleration voltage. The chemical composition of the coatings was determined using an X-ray energy-dispersive spectrometer (EDS, Edax, Inc., Mahwah, NJ, USA).

The surface examinations, with used linear roughness measurement, were performed with the atomic force microscopy (MFP-3D, Oxford Instruments Asylum Research Inc., Santa Barbara, CA, USA) at the Université Bordeaux, France. The surface topography was assessed in the noncontact mode at a force $50 \mathrm{mN}$. The roughness index $R_{\mathrm{a}}$ was estimated within an area of $5.0 \mu \mathrm{m} \times 5.0 \mu \mathrm{m}$.

The X-ray diffraction studies were carried out at the Gdansk University of Technology, Faculty of Applied Physics and Mathematics, with the use of X-ray diffractometer (Philips X'Pert Pro-MPD, Brighton, UK) system with a vertical T-T goniometer (190-mm radius). The X-ray source was a long-fine-focus, ceramic $\mathrm{X}$-ray tube with $\mathrm{Cu}$ anode. The standard operating power was $40 \mathrm{kV}$, $50 \mathrm{~mA}(2.0 \mathrm{~kW})$. The system optics consisted of programmable divergence, anti-scatter and receiving slits, incident and diffracted beam Soller slits, curved graphite diffracted beam monochromator and a proportional counter detector (Bragg-Brentano parafocusing geometry $\left(2 \theta\right.$ ca. $5^{\circ}-100^{\circ}$ ). The spectroscopic examinations of the grown oxide layers were performed with the Raman spectrometer (Horiba Jobin Yvon Gmbh, Bensheim, Germany) at the Max Bergmann Centrum of Biomaterials, Dresden Technical University.

The glow discharge optical emission spectroscopy (GDOES) tests were carried out at the University of Bordeaux, using the GD-Profiler 2 (Horiba Jobin Yvon IBH Ltd., Glasgow, UK). The measurements were performed using the following process parameters: a glow discharge source (argon plasma) at $700 \mathrm{~Pa}$ and $30 \mathrm{~W}$, measurement time $120 \mathrm{~s}$.

The nanoindentation tests were performed with the NanoTest Vantage (Micro Materials, Wrexham, UK) equipment using a Berkovich three-sided pyramidal diamond. The maximum applied force was equal to $5 \mathrm{mN}$, the loading and unloading times were set at $20 \mathrm{~s}$, the dwell period at full load was $10 \mathrm{~s}$. The distances between the subsequent indents were $50 \mu \mathrm{m}$. During the indent, the load-displacement curves were determined using the Oliver and Pharr method. Based on the load-penetration curves, the surface hardness $(H)$ and reduced Young's modulus $(E)$ were calculated using the integrated software. The critical process parameters included the maximum force, holding time and test rate. In calculating Young's modulus $(E)$, a Poisson's ratio of 0.3 was assumed for the titanium oxide layer. The measurements were processed in randomly selected five points for each surface, and the results were averaged.

The electrochemical measurements of corrosion parameters were performed by a potentiodynamic mode in the Ringer's solution. The simulated body fluid was obtained by dissolving a Ringer's tablet (Merck KGaA, Darmstadt, Germany; each tablet contained $1.125 \mathrm{~g} \mathrm{NaCl}, 0.0525 \mathrm{~g} \mathrm{KCl}, 0.03 \mathrm{~g}$ $\mathrm{CaCl}_{2}$ and $0.025 \mathrm{~g} \mathrm{NaHCO}_{3}$ ) in $0.5 \mathrm{~L}$ of distilled water at $20{ }^{\circ} \mathrm{C}$. Different $\mathrm{pH}$ levels were obtained by adding the hydrochloric acid ( $5 \mathrm{wt} . \%$ to the solution.-Lowering of $\mathrm{pH}$ even to 3 resembled acidic environmental conditions during inflammation [64], so the test was carried for $\mathrm{pH}$ ranging from 7 (normal physical state) through 5 to 3 (inflammatory state). A standard three-electrode electrochemical cell was used comprising of a saturated calomel electrode (SCE) as the reference electrode, a platinum electrode as the counter electrode and the sample as the working electrode (anode). All experiments were performed using a potentiostat/galvanostat (VersaSTAT 4, Ametek Scientific Instrumentation, Leicester, UK). Before the test, the samples were stabilized at their open circuit potential (OCP) for $0.5 \mathrm{~h}$. Potentiodynamic polarization tests were carried out at a potential change rate of $10 \mathrm{mV} / \mathrm{min}$, within a scan range from -2 to $2.5 \mathrm{~V}$. The corrosion potential $E_{\text {corr }}$ and corrosion current density $i_{\text {corr }}$ were determined from the polarization curves using the Tafel extrapolation method. 
The water contact angle (wettability) measurements were taken for the reference Ti-13Nb-13Zr alloy and oxidized specimens using a contact angle goniometer (Attension Thete Lite, Dyne Technology, Lichfield, UK) at room temperature. All analyses were repeated three times for each sample.

Studies of antibacterial activity of nanotubular surfaces were carried out at the Gdansk University of Technology, Faculty of Chemistry, with the Staphylococcus aureus ATCC25923 strain. The samples were put in $5 \mathrm{~mL}$ of bacterial suspension (containing at least $10^{6}$ colony forming units (CFU) in $1 \mathrm{~cm}^{3}$ ) prepared in phosphate buffered saline (PBS, chemical composition 8.0-g/L NaCl, $0.2-\mathrm{g} / \mathrm{L} \mathrm{KCl}, 1.44-\mathrm{g} / \mathrm{L}$ $\left.\mathrm{Na}_{2} \mathrm{HPO}_{4}, 0.24-\mathrm{g} / \mathrm{L} \mathrm{KH}_{2} \mathrm{PO}_{4}\right)$ ), in which they stayed for $1 \mathrm{~min}$. This step of the procedure aimed to allow the bacterial cells to adsorb on the surfaces of the tested materials. Next, the samples (with bacteria adsorbed on their surfaces) were transferred to $5 \mathrm{~mL}$ of sterile TSB medium placed in the 8-well microplates. The samples were incubated at $37^{\circ} \mathrm{C}$ for $24 \mathrm{~h}$ (one day) or $120 \mathrm{~h}$ ( 5 days). Subsequently, the samples were removed carefully from TSB medium and rinsed by submersion three times in a sterile saline solution $(0.9 \% \mathrm{NaCl})$. Afterward, the samples were placed in the wells of a new titration plate containing $5 \mathrm{~mL}$ of MTT (3-(4,5-dimethyl-2-thiazolyl)-2,5-diphenyl-2H-tetrazolium bromide) solution $(0.3 \%)$ in PBS. The living cells of bacteria reduce MTT to insoluble in water violet formazan crystals, and the amount of formed formazan is proportional to the number of live bacteria that are still present (in the form of biofilm) on the surfaces. Following $2 \mathrm{~h}$ incubation at $37^{\circ} \mathrm{C}$ in the dark, the solution of MTT in PBS was carefully removed from the wells and replaced with $5 \mathrm{~mL}$ of DMSO for dissolving formed formazan crystals. The optical density of the obtained solutions was measured at $540 \mathrm{~nm}$ using a Victor ${ }^{3}$ microtiter reader (PerkinElmer, Waltham, MA, USA).

Cytotoxicity tests were performed at the Warsaw Medical University, Department of Dental Surgery. They were carried out on the titanium alloy and the oxidized surfaces of the samples. Experiments were performed on fibroblasts obtained from neonatal rat Lewis Op/Op after the third passage. A small microscope slide was placed into small plastic plates with a diameter of $35 \mathrm{~mm}$ (430165, Corning Manufacturer, Corning, NY, USA). For all of them, except for control plates, single titanium samples were filled with a suspension of cells in the culture medium. All plates received 100,000 cells suspended in $2.0 \mathrm{~mL}$ medium. After five days, the slides with the cells deposited on them were rinsed with physiological saline and preserved in a mixture of methanol and acetic acid (3:1) for $5 \mathrm{~min}$, then stained with hematoxylin and eosin. The preparations were dehydrated with DPX (a mix of distyrene, a plasticizer and xylene), dried and subjected to microscopic evaluation. The density of cultured cells and their morphologic features, as well as the presence of forms of mitotic divisions, were assessed. The evaluation of each sample was carried out three times.

\section{Results}

\subsection{Microstructure, Surface Topography, Phase and Chemical Compositions}

Figure 2 presents the morphology of the oxide coatings. They all were homogenous and transparent, but the interference of reflected light resulted in a color effect related to the applied voltage and resultant thickness of the oxide layer and its structure. The samples after EO1 treatment showed a blue color (Figure 2a), typical of titanium oxidized at $40 \mathrm{~V}$ and resulting in the thickness of about $74 \mathrm{~nm}$ [65]. The oxide coatings obtained after EO2 treatment and EO1 + EO2 modification were matt-gray as expected for nanotubular layers.

The observations of the surfaces of oxide coatings revealed a homogenous and even surface after EO1 treatment (Figure 2a) and an appearance of nanotubes after EO2 (Figure 2c) and EO1 + EO2 (Figure 2e) surface modifications.

The measurement of the thickness of the thin EO1 coating was challenging as before oxidation, the surface was mirror-like, and there were reflections from the surface. The results of measurements based on the cross-sections of the samples (Figure $2 b, d, f$ ) showed that the EO1 coating was about 80-nm-thick (Figure 2b), in perfect accordance with the previously cited report, the EO2 coating was about 1000-nm-thick (Figure 2d), and the EO1 + EO2 coating had similar thickness. However, the last 
coating could be supposed to compose of two zones: typical nanotubular outer layer and an inner layer of presumably different view as discussed later (Figure $2 \mathrm{f}$ ).

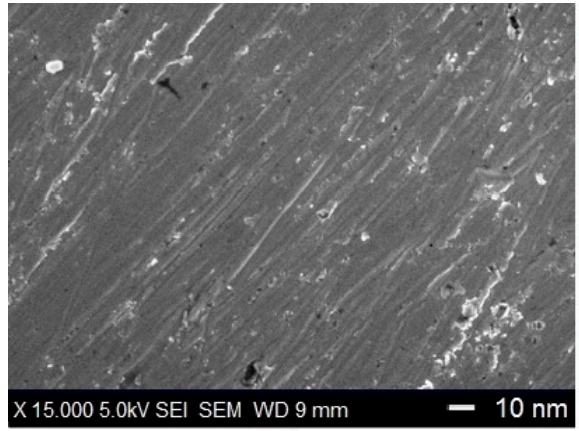

a)

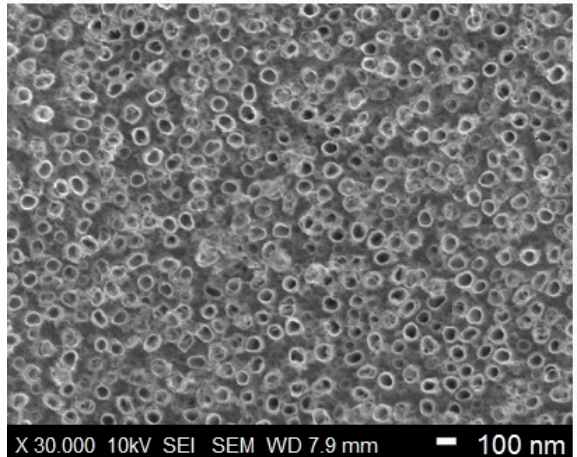

c)

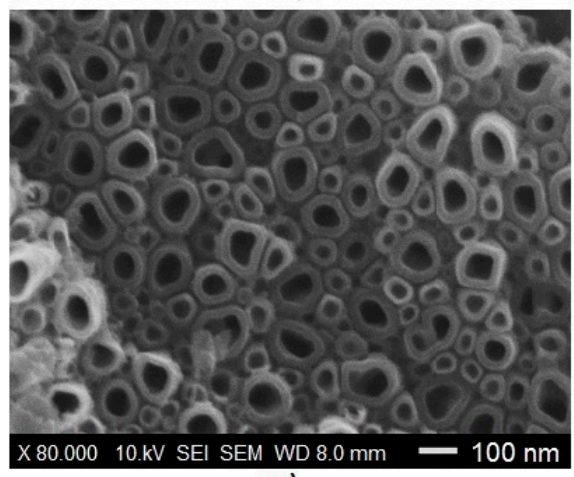

e)

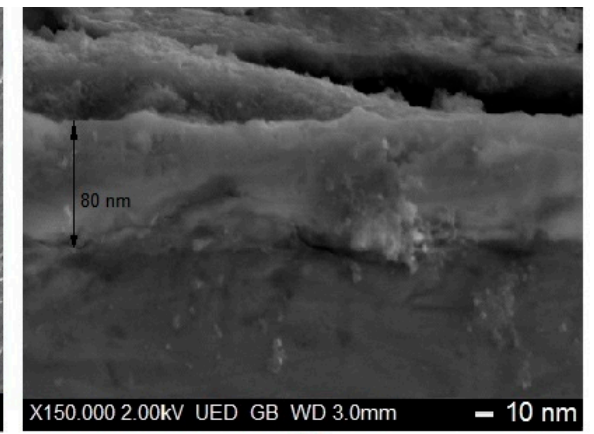

b)

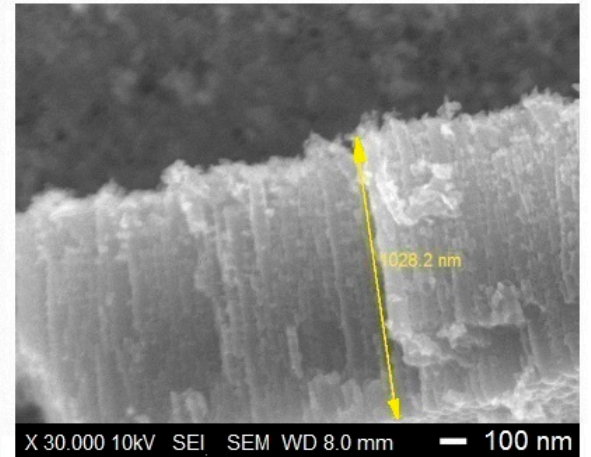

d)

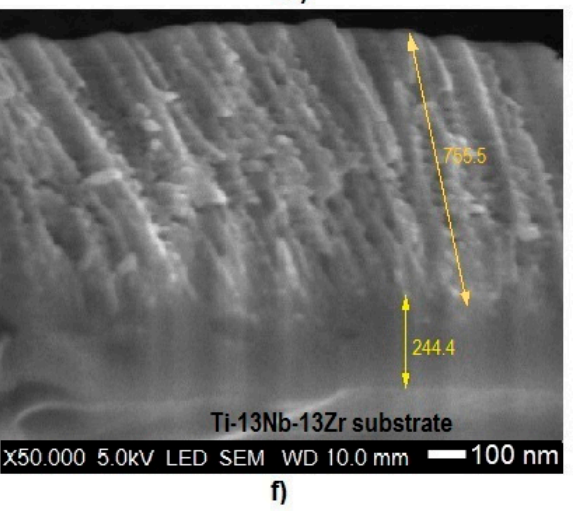

Figure 2. Images SEM - comparison of (a) alloy after amorphous layers (EO1) treatment (surface); (b) alloy after EO1 treatment (cross-section); (c) alloy after nanotubular layer (EO2) treatment (surface); (d) alloy after EO2 treatment (cross-section); (e) alloy after EO1 + EO2 treatment (surface), (f) alloy after EO1 + EO2 treatment (cross-section).

Figure 3 shows the surface coating topography after different electrochemical oxidation and Table 2 presents the roughness of coatings. After EO1 treatment, the smoothest layer, even compared to the polished material, was observed. The EO2 (not shown in figure) and EO1 + EO2 coatings were characterized by slightly increased roughness than the EO1 and substrate material. 


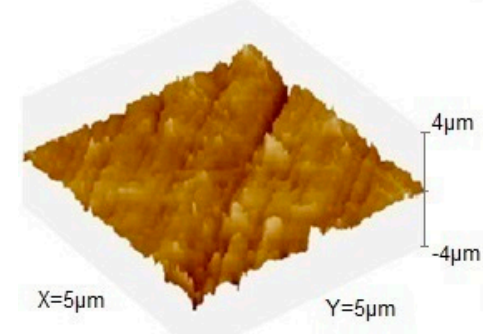

a)

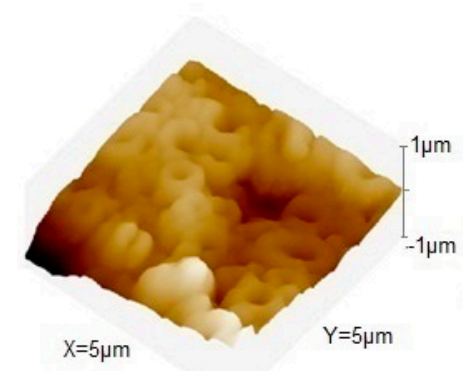

c)

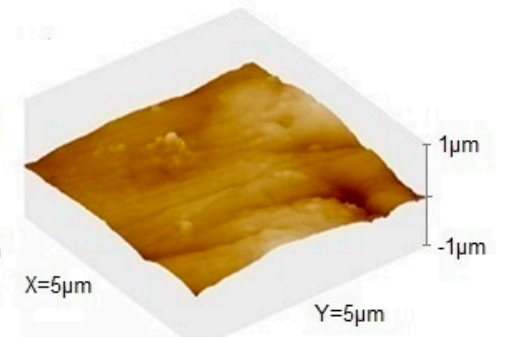

b)

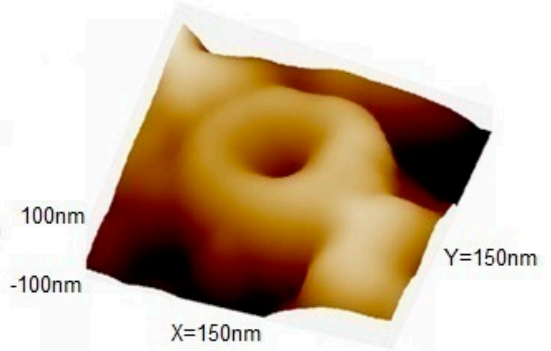

d)

Figure 3. Atomic Force Microscope (AFM) images of the surface topography. (a) Substrate titanium alloy; (b) alloy after EO1 treatment; (c) alloy after EO1 + EO2 treatment; (d) a single nanotube.

Table 2. Roughness parameters $\left(R_{\mathrm{a}}\right)$ in the area of $200 \times 200 \mathrm{~nm}^{2}$.

\begin{tabular}{cc}
\hline Sample & $\boldsymbol{R}_{\mathbf{a}}$ Parameter $(\mathbf{n m})$ \\
\hline Ti-13Nb-13Zr & $25 \pm 5$ \\
EO1 & $5 \pm 2$ \\
EO2 & $36 \pm 11$ \\
EO1 + EO2 & $32 \pm 10$ \\
\hline
\end{tabular}

The chemical composition of the layers determined by EDS measurements is demonstrated in Table 3. However, because of the oxide volume and thickness examined by the EDS, which exceeds that of the oxide coating of the EO1 sample, the data for this specific case could be result from both thin oxide coating and the alloy. The oxygen content in each coating was determined from stoichiometry, assuming that it formed the stoichiometric oxides.

Table 3. EDS examinations of tested specimens.

\begin{tabular}{cccc}
\hline Element & $\begin{array}{c}\text { EO1 Treatment } \\
\text { wt.\% }\end{array}$ & $\begin{array}{c}\text { EO2 Treatment } \\
\text { wt.\% }\end{array}$ & $\begin{array}{c}\text { EO1 + EO2 Treatment } \\
\text { wt.\% }\end{array}$ \\
\hline $\mathrm{O}$ & 41.34 & 56.20 & 52.61 \\
$\mathrm{Ti}$ & 45.30 & 25.98 & 27.06 \\
$\mathrm{~F}$ & - & 3.50 & 3.53 \\
$\mathrm{Nb}$ & 3.21 & 6.72 & 9.51 \\
$\mathrm{Zr}$ & 5.50 & 5.84 & 9.02 \\
$\mathrm{P}$ & 1.12 & 1.76 & 1.80 \\
\hline
\end{tabular}

$\left(^{*}\right)$ quantities, in this case, must be regarded as only informative.

The Raman spectra of the titanium alloy are shown in Figure 4. According to previous research [66], the Raman spectra for the EO1 coating should display clear signs of the anatase phase four-peak pattern with peaks at $575 \mathrm{~cm}^{-1}$ deriving from $v_{1}$ vibrations being the strongest and the other peaks at 144,198 and $406 \mathrm{~cm}^{-1}$ being much weaker. These peaks come from anatase [67,68]. However, here, the small rutile band was observed at 238 and $612 \mathrm{~cm}^{-1}$. For the EO1 + EO2 coating, the intensity of 
the band $313 \mathrm{~cm}^{-1}$ increased and moved to higher frequencies; these peaks originated from the $\mathrm{TiO}_{2}$ band [68]. A very similar situation was noticed for the $198 \mathrm{~cm}^{-1}$ peak, which also came from anatase. These findings are in agreement with XRD characterization showing $\mathrm{TiO}_{2}$-specific peaks (for anatase and rutile phases). The Raman spectra of here examined samples are similar to those reported for titanate crystal formed of nanotubes [69].

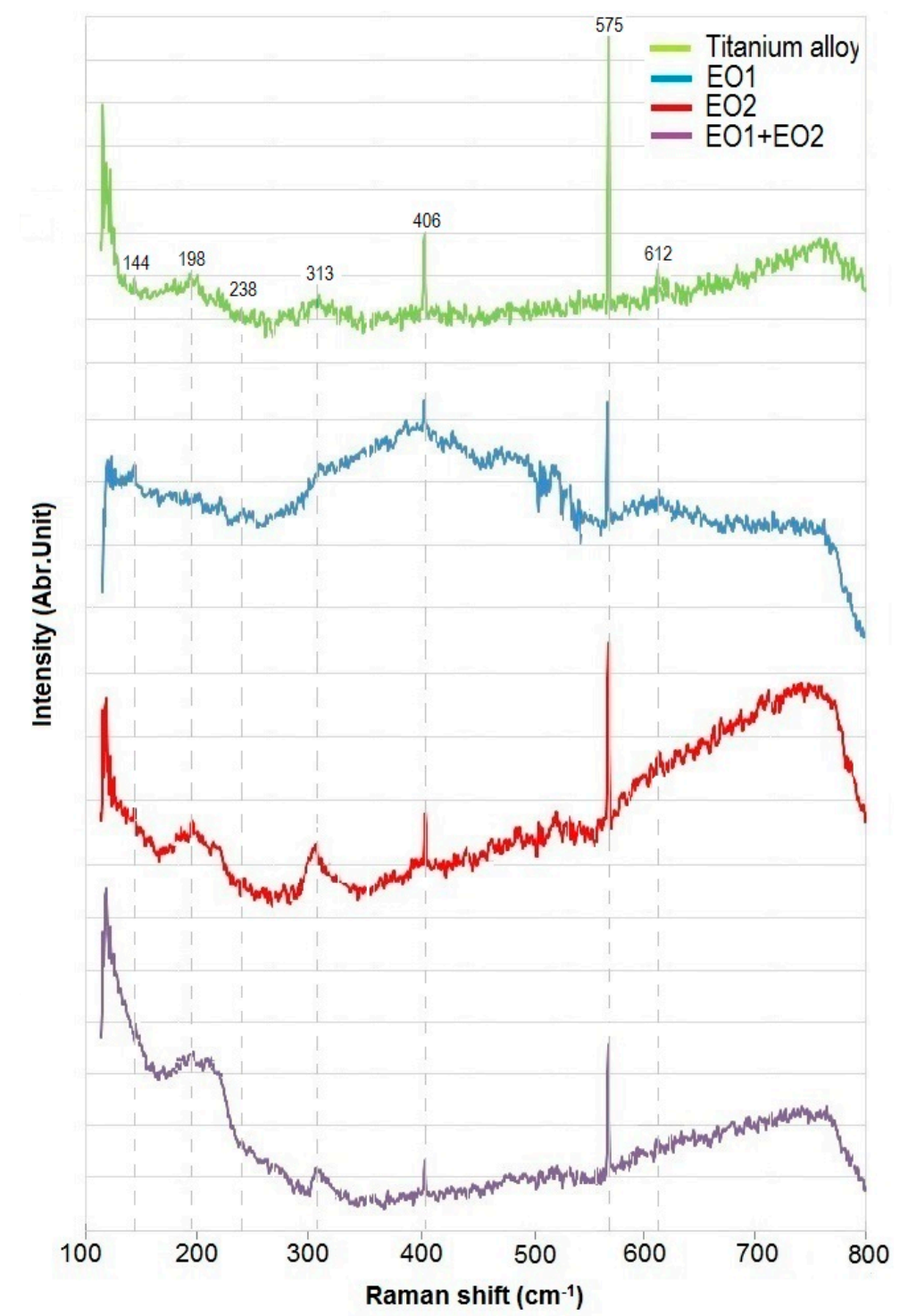

Figure 4. Raman spectra of the oxide coatings for a non-oxidized substrate and after different electrochemical oxidation.

As a result of the GDOES measurements, the values of wavelengths emitted by the excitation of atoms appear for all here present elements, as shown in Figure 5. For the Ti-13Nb-13Zr alloy (Figure 5a), the distribution of elements with erosion (sputtering) time was abrupt and remained at a certain level. For the oxidized EO1 sample (Figure $5 b$ ), the maximum intensity for oxygen occurred in the initial phase of the measurement, significantly exceeding the value of the peak derived from titanium, which decayed very quickly. The distribution of the intensity values of particular elements for the EO2 (Figure 5c) and EO1 + EO2 (Figure 5d) coatings was different. In the case of the EO1 + EO2 coating, in the initial phase of the study, there were distinct fluctuations in the intensity of the main alloying elements: $\mathrm{Ti}, \mathrm{Nb}$ and $\mathrm{Zr}$. The differences in the intensity of the elemental distribution with erosion time are visible, which may be due to different thicknesses of the tested coatings. 


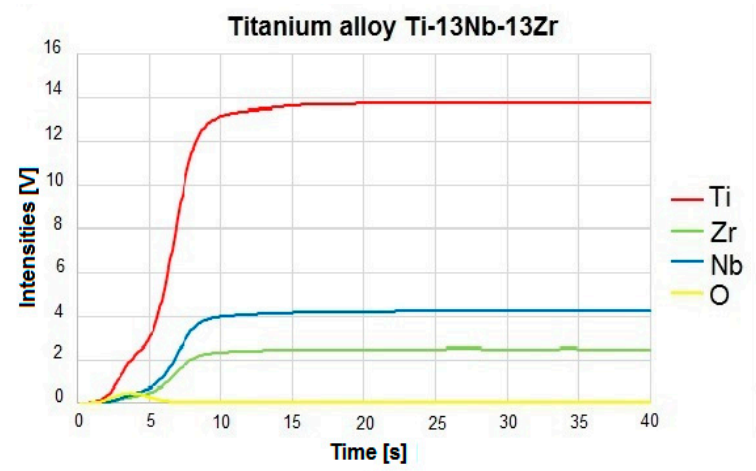

a)

E02

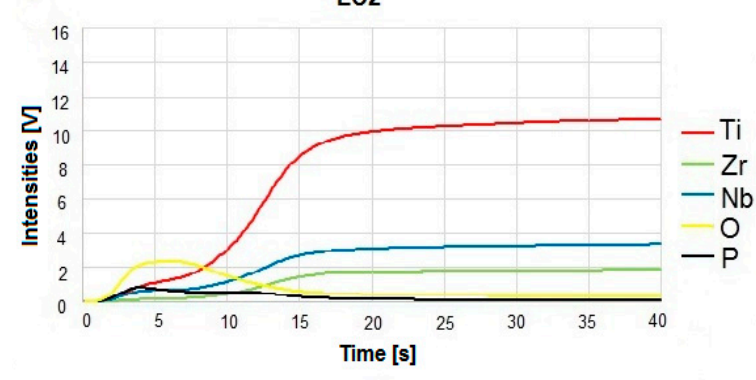

c)

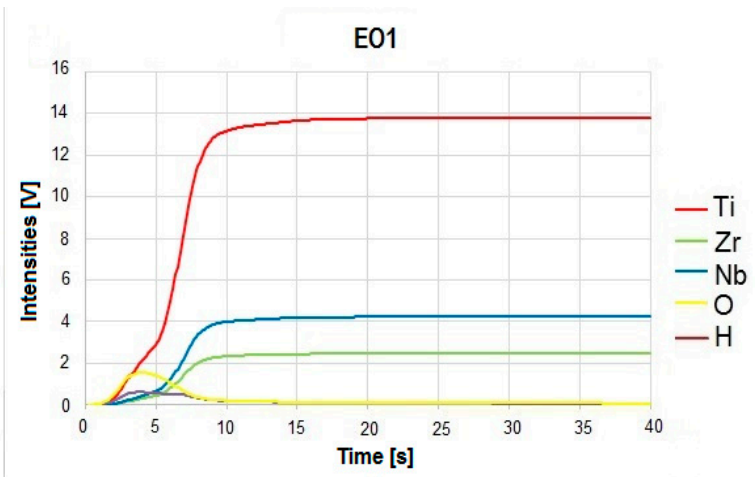

b)

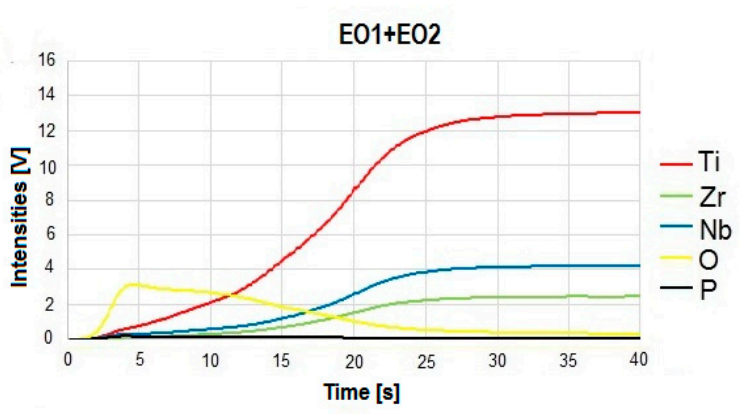

d)

Figure 5. Glow discharge optical emission spectroscopy (GDOES) analysis results. (a) Ti-13Nb-13Zr alloy; (b) alloy after EO1 treatment; (c) alloy after EO2 treatment; (d) alloy after EO1 + EO2 treatment.

Analyzing the XRD diagrams (Figure 6) and based on the literature data [70-72], for each sample the characteristic reflexes corresponding to the positions of the $\alpha$-Ti phase and $\beta$-Ti can be found (Figure 6a). Depending on the sample, they differ in intensity and width. In all tested samples, several reflexes from both crystallographic structures were found at appropriate angles.

For oxidized specimens, the reflexes from anatase were observed at three positions, and from rutile-only at one. Due to the overlapping of peaks from titanium and titanium oxide, the crystalline structure of the titania nanotubes could not be determined. A slight decrease in the intensity of the peaks for the EO1 (Figure 6b) sample was observed. In the case of EO1 + EO2 coating (Figure 6d), it became necessary to reduce the reflex intensities of both phases ( $\alpha$-Ti and $\beta$-Ti) in comparison with the EO2 coating (Figure 6c). A much more significant decrease in the intensity of the reflexes from the $\beta$-Ti phase was observed compared to the reduction of the $\alpha$-Ti phase, perhaps due to the presence of oxygen. Most likely, the reflection intensity depends on the thickness of the layer; the thicker the layer, the higher the reflex intensity. This result appeared for all oxidized specimens for which a significant increase in reflex intensity was observed. It is worth noting that the primary reflexes from the oxide phase were distinctly the highest for the EO1 + EO2 sample.

\subsection{Nanomechanical Properties}

The nanohardness, microhardness and Young's modulus values of the specimens are shown in Table 4. The tests showed an increase in both hardness values and Young's modulus for oxidized samples.-When considering Young's modulus, the highest value was obtained for the EO1 coating. Similar results were obtained for the nanoparticle layer and hybrid coating. 


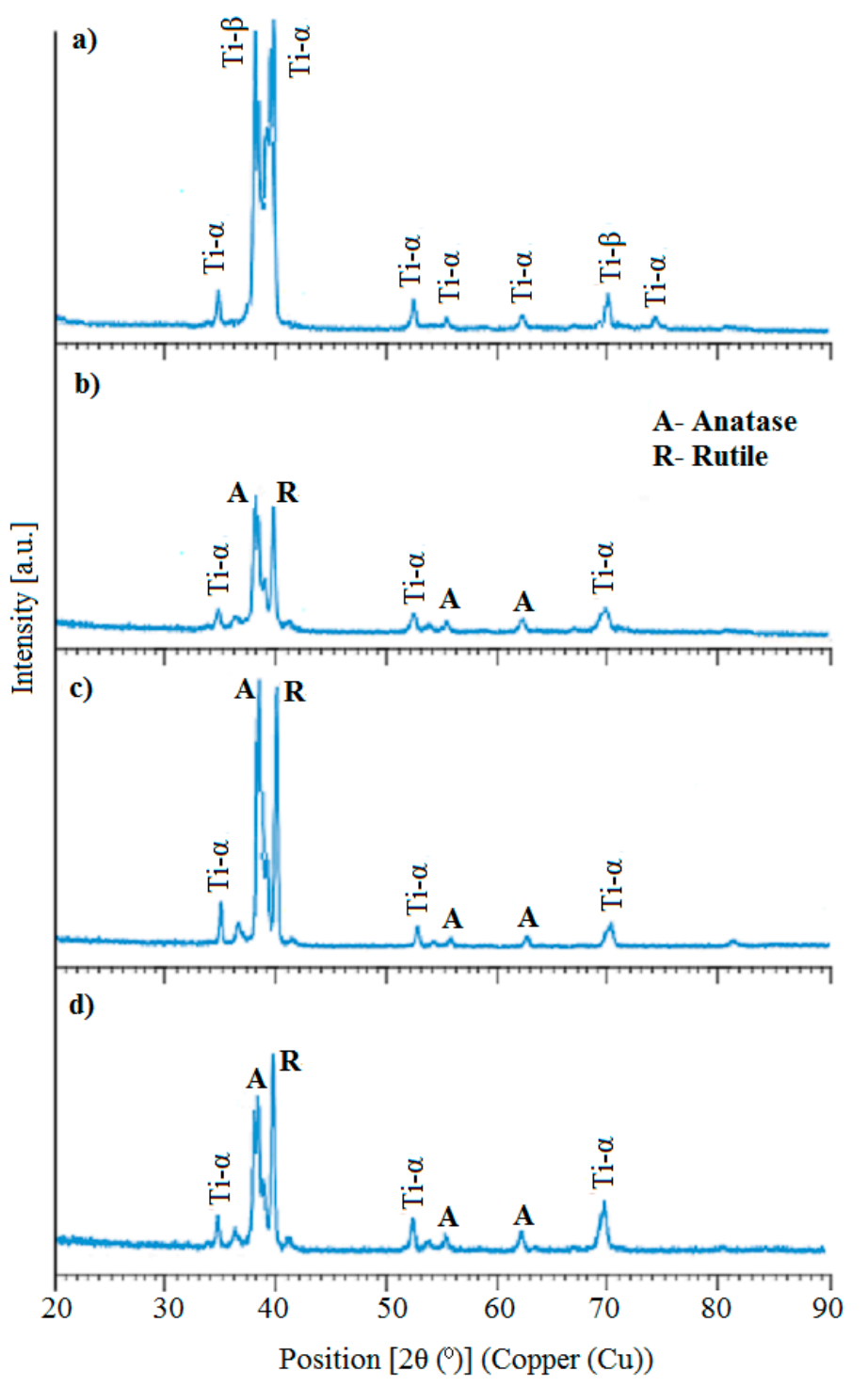

Figure 6. XRD spectra. (a) Alloy Ti-13Nb-13Zr; (b) alloy after EO1 treatment; (c) alloy after EO2 treatment; (d) alloy after EO1 + EO2.

Table 4. Mechanical properties of the tested specimens.

\begin{tabular}{ccccc}
\hline Sample & $\begin{array}{c}\text { Max. Depth } \\
\text { (nm) }\end{array}$ & Plastic Depth $(\mathbf{n m})$ & $\begin{array}{c}\text { Hardness } \\
\text { (GPa) }\end{array}$ & $\begin{array}{c}\text { Young's Modulus } \\
\text { (GPa) }\end{array}$ \\
\hline Ti-13Nb-13Zr & $778 \pm 17$ & $455 \pm 1$ & $0.09 \pm 0.06$ & $44.30 \pm 0.25$ \\
EO1 & $158 \pm 33$ & $152 \pm 1$ & $1.01 \pm 0.22$ & $65.24 \pm 4.13$ \\
EO2 & $138 \pm 48$ & $128 \pm 1$ & $2.03 \pm 0.33$ & $57.30 \pm 3.87$ \\
EO1 + EO2 & $241 \pm 15$ & $228 \pm 4$ & $2.71 \pm 0.42$ & $59.73 \pm 4.09$ \\
\hline
\end{tabular}

An increase in hardness of one order of magnitude was observed for samples with the compact oxide layer. For samples with the EO2 and EO1 + EO2 coatings, the values were similar, much higher compared to polished alloy or the compact layer. The main factor influencing the change in hardness is the thickness of the oxide layer [73-75]. The small thickness of the compact solid layer (80 nm) could cause some errors in the nanoindentation test. It is well known that the response is not only be given by the first indented layer, but the substrate or the subsequent layers may also contribute to the 
indentation response [76]. In both cases, the thickness of the nanotubular layer (EO2) was so large that there was no response from the substrate.

\subsection{Wettability}

The results of measurements of water contact angle are presented in Table 5. The decrease of the contact angle was small for the EO1 and significant for the other coatings. The created surfaces were hydrophilic. The most desirable value of contact angle for regeneration applications in hard tissues ranges from $35^{\circ}$ to $80^{\circ}$ [77].

Table 5. Contact angle for the water droplet for the tested specimens.

\begin{tabular}{cc}
\hline Sample & Average Angle $\left(^{\circ}\right)$ \\
\hline $\mathrm{Ti}-13 \mathrm{Nb}-13 \mathrm{Zr}$ & $83.0 \pm 2.4$ \\
$\mathrm{EO} 1$ & $78.9 \pm 1.7$ \\
$\mathrm{EO} 2$ & $29.2 \pm 1.4$ \\
$\mathrm{EO} 1+\mathrm{EO} 2$ & $48.8 \pm 1.6$ \\
\hline
\end{tabular}

\subsection{Corrosion Properties}

The corrosion test results are presented in Figure 7. The polarization curves were S-shaped. The decrease in $\mathrm{pH}$ value always resulted in a shift of corrosion potential to a more active area. However, the appearance of thin, compact oxide coating slightly worsened the corrosion behavior, and the EO1 $+\mathrm{EO} 2$ treatment caused an opposite effect-a shift of the corrosion potential to the more noble area. The corrosion current values can be determined if the Tafel straight lines in potentiodynamic curves (at logarithmic scale) are sufficiently long (at least two decades). Here, this condition has not been fulfilled. Therefore, there is no sufficient base to calculate the corrosion current densities.

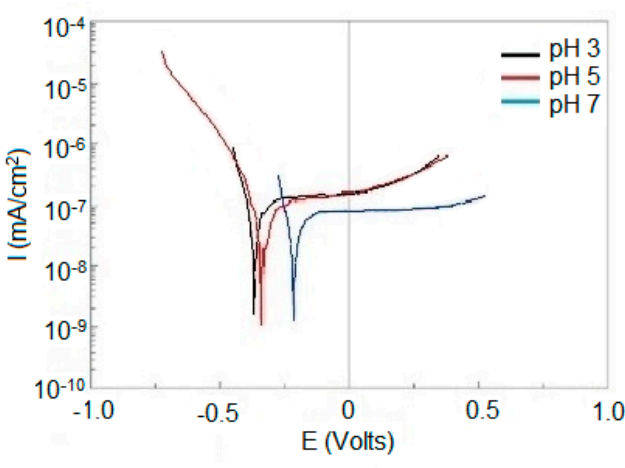

a)

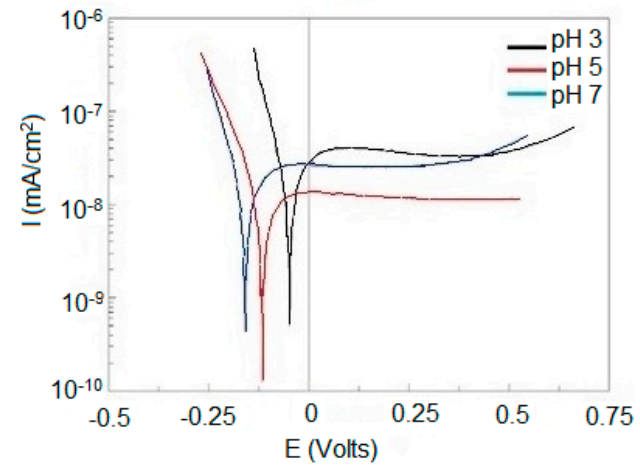

c)

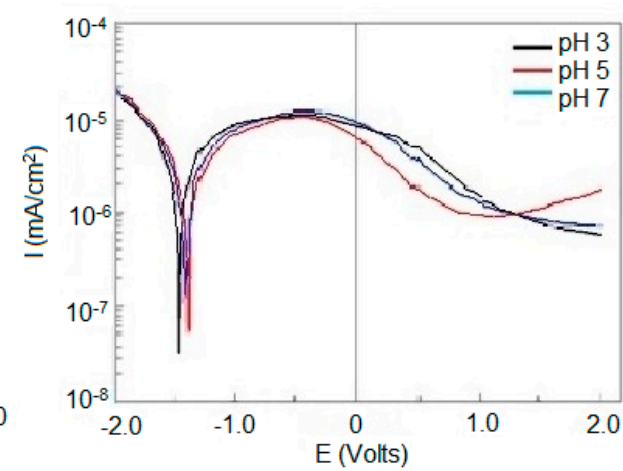

b)

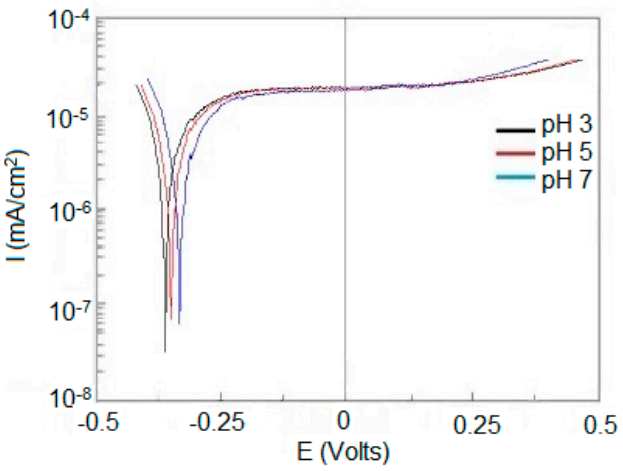

d)

Figure 7. Potentiodynamic polarization curves at different $\mathrm{pH}$. (a) Ti-13Nb-13Zr; (b) EO1 sample; (c) EO2 sample; (d) EO1 + EO2 sample. 


\subsection{Antibacterial Properties}

Figure 8 presents the images illustrating the intensity of biofilm formation on the surfaces of materials, measured by absorbance values of solutions of formazan (diluted in DMSO) produced by live cells of bacteria from MTT. After one-day exposure, the lowest absorbance values were observed for the reference and the EO1 samples. The presence of nanotubular surface distinctly increased biofilm formation. In contrast, even the biofilm increased in five days, the lowest levels were attained for the $\mathrm{EO} 2$ and EO1 + EO2 samples, for which only a slight difference was noticed between the first and fifth days.

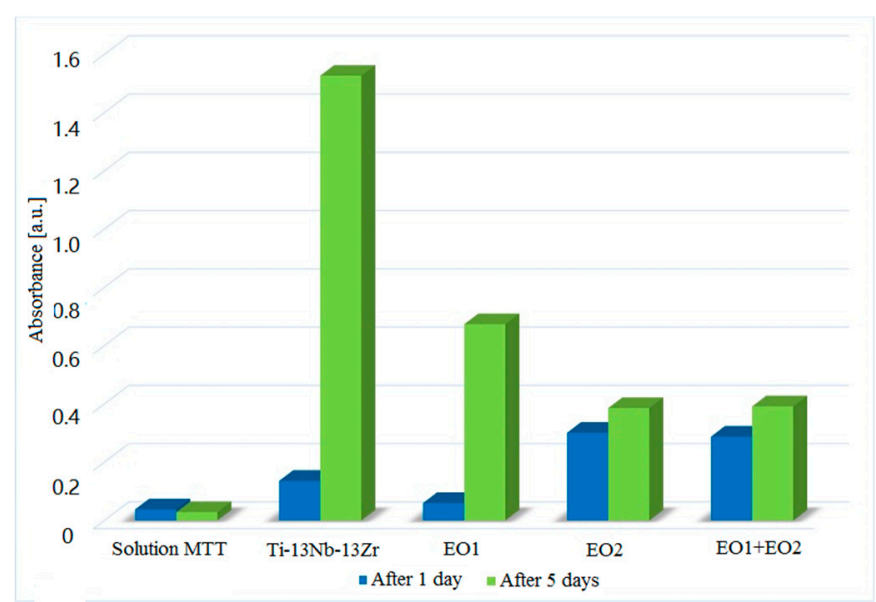

Figure 8. Growth of bacterial film of Staphylococcus aureus strain on the tested samples surfaces.

\subsection{Cytotoxicity}

In these tests (Figure 9), five-day-old cultures formed a reasonably even layer of cells (monolayers), with a large number of figures of mitotic divisions: prophase and metaphase, a small number of polymorphs with no signs of cell damage. The images of cell culture on the surface of the non-oxidized alloy, as well as of the oxidized samples, show that none of the studied surfaces deteriorated the behavior of osteoblasts.

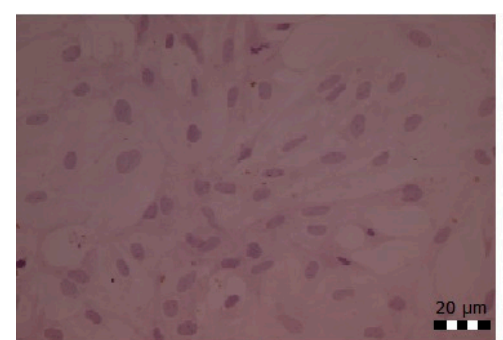

a)

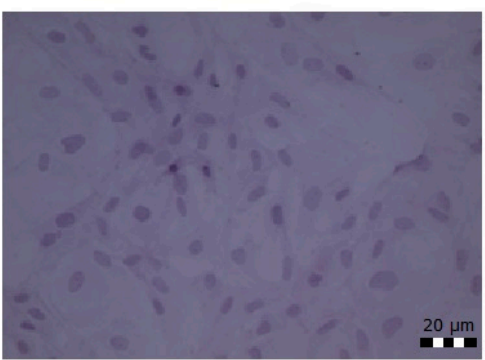

b)

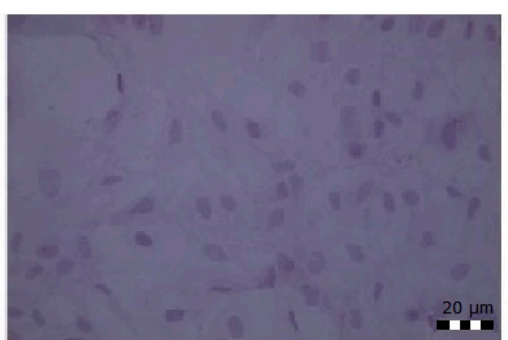

c)

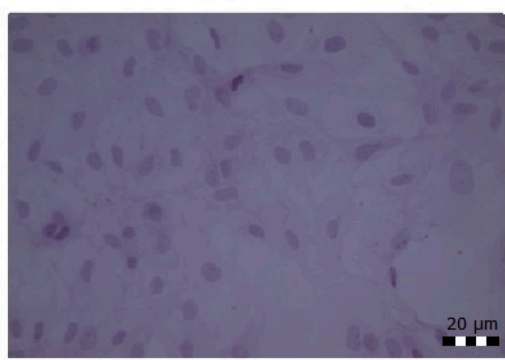

d)

Figure 9. Cytotoxic tests of fibroblastic cells. (a) Ti-13Nb-13Zr alloy; (b) EO1 sample; (c) EO2 sample; (d) EO1 + EO2 sample. 


\section{Discussion}

The two-stage oxidation could result in the bi-layer ("sandwich" layer) oxide coating as shown in [47] in which the alloy was subjected to gaseous oxidation and then to the electrochemical oxidation. The last method performed in the presence of HF acid caused the transformation of the upper part of the compact oxide coating into a nanotubular layer, resulting in both highly corrosion-resistant and bioactive coating. However, such a mechanism is possible if oxidation is performed at a high temperature at which oxygen diffusion is fast. On the other hand, with increasing compact oxide thickness, the thickness of the nanotubular layer decreases to zero because of increasing electrical resistance.

Therefore, we have attempted to create the compact oxide layer by the electrochemical method and transform it into a nanotubular layer. The thickness of the oxide coating appearing at room temperature is low because of slow oxygen diffusion, and the thickness of the nanotubular layer creating in the second stage overpasses that of the compact oxide. Therefore, at applied oxidation parameters, the creation of the bilayer coating is not possible. The inner layer shown in Figure $2 \mathrm{f}$ may be simply a part of the nanotubular layer, likely, as sometimes observed [71], the interface between the oxide layer and bare metal.

The mechanism of creation of oxide coating during two-stage anodization involves the appearance of a nanotubular layer in the second stage; initially, within the compact oxide layer and then, when the compact layer is fully transformed into the nanotubular structure, within the bare alloy structure. No double structure was observed in any image; however, it affected mechanical and chemical, but not biologic properties.

In the beginning, let us consider the similarities and differences between behavior of specimens subjected to EO2 treatment (nanotubular oxide on bare metal) and EO1 + EO2 oxidation. Neglecting the doubtful inner layer in the EO1 + EO2 sample, it may be said that the form of applied procedure does not affect the coating thickness and roughness. Moreover, the Raman spectra for EO1 + EO2 and EO2 also look very similar in the shape presenting the peaks at the same positions. Raman spectra confirm that the heat treatment of the nanotubes transforms them from the amorphous to the crystalline structure. However, the thickness of the compact oxide layer is much lower than that of the nanotubular layer. It is because the single electrochemical oxidation is determined only by oxygen diffusion, and the growth of the nanotubular layer is much faster as determined by the chemical reaction of etching, being relatively quick. The appearance of the nanotubular structure is an obvious explanation of surface roughness distinctly higher than that of the compact oxide.

The question is, what causes the difference between EO2 is and EO1 + EO2 coatings in some their properties? It may be microstructure, but such results are very difficult to observe. We believe that it is an enrichment with oxygen of the upper zone of the oxide coating after EO1 + EO treatment. The EDS examinations do not confirm this assumption, but their precision is low. However, the GDOES experiments-in which the slower erosion rate and higher oxygen intensity in the EO1 + EO2 coatings compared to EO2 coating - may be an evidence of above proposed phenomenon. Physically, oxygen in the previous oxide layer may occupy also interstices making a microstructure more resistant to diffusion of other elements, more mechanically resistant and more resistant to corrosion by creating the oxides in existing imperfections.

The XRD results are similar for both EO2 and EO1 + EO2 oxidation procedures. The appearance of both rutile and anatase in the oxide layers has been detected what may be surprising as such transformation may occur at temperatures beginning from $450^{\circ} \mathrm{C}$ [72], $500^{\circ} \mathrm{C}$ [49] or even $550^{\circ} \mathrm{C}$ [71] for titanium. Here the heating temperature was $400^{\circ} \mathrm{C}$, close to the suggested beginning of transformation.

The nanoindentation tests show that the presence of nanotubular structure significantly increases hardness and Young's modulus and decreases plastic work. Such results are supported by earlier research [78]. They may result from the specific microstructure of the nanotubular layer, which is comprised of very hard nanotubular oxides, flexible and readily underwent slight deformation. The difference between those values for the EO2 sample and EO1 + EO2 coating may be attributed to the effect of higher oxygen/oxides content in the last sample surface. 
The contact angle measurements show an increase in wettability for both EO2 and EO1 + EO2 coatings. The present values permit to classify both surfaces as potentially biocompatible, which may attract proteins and pre-osteoblasts. There have been some assumptions about the best values contact angle for cell attachment assessed at $55^{\circ}$ and for bone regeneration from $35^{\circ}$ to $80^{\circ}$ [70,77]. Here found contact angle values, about $29^{\circ}$ for nanotubular layer and $49^{\circ}$ for hybrid coating are favorable for biochemical adsorption processes.

The corrosion resistance of titanium alloys is well-known to increase after oxidation. The behavior of the potential beginning from a fast decrease rate followed by a slow rise is typical for a partial stabilization of current density and formation of the highly protective passive film. The current density stabilization suggests the passive film breakdown, in a way similar to what occurs during pitting nucleation and repassivation. Electrochemical potentiodynamic studies have shown how significantly the corrosion quality is affected by the surface quality and thickness of the obtained layers [79,80]. An increase in corrosion resistance of samples covered with amorphous layers (EO1) is visible. The compact, uniform layer provides better corrosion resistance, comparable with spontaneous oxide layers. In the case of EO2 layers (Figure 7c), no decrease in resistance to corrosion was expected. The nanotubes are hollow, and there are voids between them, which were corrosion tunnels - potential places for corrosion development. Saji et al. [81] have observed an increase in the resistance of the oxide layer with a nanotube structure. However, for the $\mathrm{Ti}-\mathrm{Nb}-\mathrm{Ta}-\mathrm{Zr}$ alloy, the same authors observed a decrease in corrosion resistance of the nanotubular layer [82]. The thickness of such a layer may play an important role, as it is a barrier to the progression of corrosion [80]. From performed research it follows that a nanotubular layer does not form a suitable protection against corrosion. However, the EO1 + EO2 coating obtained by the electrochemical method shows nobler corrosion potential and likely better corrosion resistance compared to the nanotubular EO2 layer.

The attachment of bacteria to the solid surfaces of different chemical compositions, including alloy surfaces, is affected by the electrostatic double layer, hydrophobicity, roughness and various other factors [83-85]. Bacteria need to overcome the energy barriers to reach the negative energy regions, thereby facilitating the bacterial attachment [86]. In our experiment, we observed a rather moderate development of the population of bacterial cells attached (a bacterial biofilm) to the surfaces of all materials tested after $24 \mathrm{~h}$ of incubation. It confirms that some cells of $S$. aureus were able to adsorb on the surfaces of all materials. The MTT assay revealed a bit higher number of bacteria on surfaces of EO2 and EO1 + EO2 compared to EO1 and Ti-13Nb-13Zr. However, no drastic differences were observed between oxidized and non-oxidized specimens in the level of bacterial content after 1st day of incubation.

In contrast, the bacteria development on the non-oxidized alloy drastically increased during the following five days of incubation up to their highest level. In the case of this material, the value of absorbance in MTT assay, which is a consequence of the number of bacteria and the amount of reduced MTT to formazan, reached a value of about 1.5 compared to 0.6 , for EO1 and about 0.4 for EO2 and $\mathrm{EO} 1+\mathrm{EO} 2$. Moreover, in the case of the samples subject to EO2 or EO1 + EO2 oxidation, the levels of bacterial content (biofilms) after one and five days were comparable, which confirms bacterial growth inhibition on the surfaces of these materials which is their essential advantage. The observed influence of the presence of a nanotubular oxide layer on the bacteria attachment or growth inhibition was already reported $[87,88]$. It may be attributed to the influence of surface topography on the adhesion of bacteria, and it is an evidence that the presence of oxide nanotubes prevents to some extent, thanks to the specific layer microstructure, the danger of bacteria inflammation. The different strategies to avoid infection onto titanium surfaces have been reported: surface modification and coatings by antibiotics, antimicrobial peptides, inorganic antibacterial metal elements and antibacterial polymers [89], but a presence of nanotubular crystalline titanium dioxide also could be useful.

The introduction of nanomaterials and nanostructures may affect the osseointegration processes [90], but also may develop cytotoxicity as several nanomaterials. In our tests (Figure 9), after 
five days, no cytotoxic effects against the osteoblasts were noticed. These results are following some previous reports [34].

Summarizing it can be said that the application of oxidation joined with etching by HF acid has a different effect on mechanical and chemical properties depending on whether the alloy or oxide coating form the surface zone. The difference can be attributed to the different microstructure within the surface zone, even if the processes leading to such a result cannot be precisely described yet. It may be a saturation of oxides with oxygen or an appearance of more close-packed nanotubes or other not recognized phenomena. This problem will be investigated in detail in the near future.

\section{Conclusions}

Two-stage Ti-13Nb-13Zr electrochemical oxidation with the use of orthophosphoric acid and subsequently hydrofluoric acid results in an improvement of several nanomechanical and chemical properties such as hardness, Young's modulus and corrosion resistance. No significant effects on biologic properties are observed.

The observed influences may be attributed mainly to the change in the chemical composition and microstructure of the upper zone of the nanotubular layer, inside which the formation of nanotubes occurs not inside the bare alloy, but in the previous anatase layer.

Following the positive effects of present tests, future research will be aimed at recognizing and modeling processes that occur during the formation of titanium oxide nanotubes on previously oxidized alloy, developing the nanotubes of thickness comparable to that of the compact oxide layer, without loss of bioactivity.

Author Contributions: Conceptualization, A.O.; methodology, A.O., J.-M.O., A.W., P.S.; validation, A.O., J.-M.O., P.S.; formal analysis, A.Z.; investigation, A.O., J.-M.O., P.S.; resources, A.O., J.-M.O., A.W., P.S.; writing—original draft preparation, A.O.; writing-review and editing, A.O. and A.Z.; All authors have read and agreed to the published version of the manuscript.

Funding: This research received no external funding.

Acknowledgments: We are grateful to Grzegorz Gajowiec (GUT) for his examinations of oxidized surfaces with the SEM and EDS, Maria Gazda (GUT) for the research and with XRD, Dieter Scharnweber and his Group from Max-Bergmann-Centrum of Biomaterials, Dresden Technical University, for Raman spectroscopy and the research staff of the Institut de Mécanique et d'Ingénierie de Bordeaux for the AFM and GDOES tests.

Conflicts of Interest: The authors declare no conflict of interest.

\section{References}

1. Ibrahim, M.Z.; Sarhan, A.A.D.; Yusuf, F.; Hamdi, M. Biomedical materials and techniques to improve the tribological, mechanical and biomedical properties of orthopedic implants-A review article. J. Alloys Compd. 2017, 714, 636-667. [CrossRef]

2. Oldani, C.; Dominguez, A. Titanium as a biomaterial for implants. Recent Adv. Arthroplast. 2012, 149-162. [CrossRef]

3. Kaur, M.; Singh, K. Review on titanium and titanium based alloys as biomaterials for orthopedic applications. Mater. Sci. Eng. C 2019, 102, 844-862. [CrossRef] [PubMed]

4. Cordeiro, J.M.; Beline, T.; Ribeiro, A.L.R.; Rangel, E.C.; da Cruz, N.C.; Landers, R.; Faverani, L.P.; Vaz, L.G.; Fais, L.M.G.; Vicente, F.B.; et al. Development of binary and ternary titanium alloys for dental implants. Dent. Mater. 2017, 33, 1244-1257. [CrossRef]

5. Prasad, S.; Ehrensberger, M.; Prasad Gibson, M.; Kim, H.; Monaco, E.A., Jr. Biomaterial properties of titanium in dentistry. J. Oral Biosci. 2015, 57, 192-199. [CrossRef]

6. Revathi, A.; Borrás, A.D.; Muñoz, A.I.; Richard, C.; Manivasagam, G. Degradation mechanisms and future challenges of titanium and its alloys for dental implant applications in oral environment. Mater. Sci. Eng. C 2017, 76, 1354-1368. [CrossRef]

7. Koizumi, H.; Takeuchi, Y.; Imaie, H.; Kawai, T.; Yoneyama, T. Application of titanium and titanium alloys to fixed dental prostheses. J. Prosthodont. Res. 2019, 63, 266-270. [CrossRef] 
8. Acciari, H.A.; Palma, D.P.S.; Codaro, E.N.; Zhou, Q.; Wang, J.; Ling, Y.; Zhang, J.; Zhang, Z. Surface modifications by both anodic oxidation and ion beam implantation on electropolished titanium substrates. Appl. Surf. Sci. 2019, 487, 1111-1120. [CrossRef]

9. Akatsu, T.; Yamada, Y.; Hoshikawa, Y.; Onoki, T.; Shinoda, Y.; Wakai, F. Multifunctional porous titanium oxide coating with apatite forming ability and photocatalytic activity on a titanium substrate formed by plasma. Mater. Sci. Eng. C 2013, 33, 4871-4875. [CrossRef]

10. Chen, X.; Chen, Y.; Shen, J.; Xu, J.; Zhu, L.; Gu, X.; He, F.; Wang, H. Positive modulation of osteogenesis on a titanium oxide surface incorporating strontium oxide: An in vitro and in vivo study. Mater. Sci. Eng. C 2019, 99, 710-718. [CrossRef]

11. Karaji, Z.G.; Hedayati, R.; Pouran, B.; Apachitei, I.; Zadpoor, A.A. Effects of plasma electrolytic oxidation process on the mechanical properties of additively manufactured porous biomaterials. Mater. Sci. Eng. C 2017, 76, 406-416. [CrossRef] [PubMed]

12. Moravec, H.; Vandrovcova, M.; Chotova, K.; Fojt, J.; Pruchova, E.; Joska, L.; Bacakova, L. Cell interaction with modified nanotubes formed on titanium alloy Ti-6Al-4V. Mater. Sci. Eng. C 2016, 65, 313-322. [CrossRef] [PubMed]

13. Tanase, C.E.; Golozar, M.; Best, S.M.; Brooks, R.A. Cell response to plasma electrolytic oxidation surface-modified low-modulus $\beta$-type titanium alloys. Colloids Surf. B Biointerfaces 2019, 176, 176-184. [CrossRef]

14. Li, H.; Zhou, D.; Zhang, Q.; Feng, C.; Zheng, W.; He, K.; Lan, Y. Vanadium exposure-induced neurobehavioral alterations among Chinese workers. Neurotoxicology 2013, 36, 49-54. [CrossRef] [PubMed]

15. Show, C.A.; Tomljenovic, L. Aluminum in the central nervous system (CNS): Toxicity in humans and animals, vaccine adjuvants, and autoimmunity. Immunol. Res. 2013, 56, 304-316. [CrossRef]

16. Asri, R.I.M.; Harun, W.S.W.; Samykano, M.; Lah, N.A.C.; Ghani, S.A.C.; Tarlochan, F.; Raza, M.R. Corrosion and surface modification on biocompatible metals: A review. Mater. Sci. Eng. C 2017, 77, 1261-1274. [CrossRef]

17. Park, J.; Bauer, S.; Von Der Mark, K.; Schmuki, P. Nanosize and Vitality: TiO2Nanotube Diameter Directs Cell Fate. Nano Lett. 2007, 7, 1686-1691. [CrossRef]

18. Chen, X.; Fan, H.; Deng, X.; Wu, L.; Yi, T.; Gu, L.; Zhou, C.; Fan, Y.; Zhang, X. Scaffold structural microenvironmental cues to guide tissue regeneration in bone tissue applications. Nanomaterials 2018, 8, 960. [CrossRef]

19. Dumas, V.; Guignandon, A.; Vico, L.; Mauclair, C.; Zapata, X.; Linossier, M.T.; Bouleftour, W.; Granier, J.; Peyroche, S.; Dumas, J.C.; et al. Femtosecond laser nano/micro patterning of titanium influences mesenchymal stem cell adhesion and commitment. Biomed. Mater. 2015, 10. [CrossRef]

20. Majkowska, B.; Jazdzewska, M.; Wołowiec, E.; Piekoszewski, W.; Klimek, L.; Zielinski, A. The possibility of use of laser-modified Ti6Al4V alloy in friction pairs in endoprostheses. Arch. Met. Mater. 2015, 60, 755-758. [CrossRef]

21. Maurel, P.; Weiss, L.; Bocher, P.; Fleury, E.; Grosdidier, T. Oxide dependent wear mechanisms of titanium against a steel counterface: Influence of SMAT nanostructured surface. Wear 2019, 430-431, 245-255. [CrossRef]

22. Huang, R.; Zhang, L.; Huang, L.; Zhu, J. Enhanced in-vitro osteoblastic functions on $\beta$-type titanium alloy using surface mechanical attrition treatment. Mater. Sci. Eng. C 2019, 97, 688-697. [CrossRef] [PubMed]

23. Ghensi, P.; Bressan, E.; Gardin, C.; Ferroni, L.; Ruffato, L.; Caberlotto, M.; Soldini, C.; Zavan, B. Osteogrowth induction titanium surface treatment reduces ROS production of mesenchymal stem cells increasing their osteogenic commitment. Mater. Sci. Eng. C 2017, 74, 389-398. [CrossRef] [PubMed]

24. Parchanska-Kowalik, M.; Wołowiec-Korecka, E.; Klimek, L. Effect of chemical surface treatment of titanium on its bond with dental ceramics. J. Prosthet. Dent. 2018, 120, 470-475. [CrossRef]

25. Asri, R.I.M.; Harun, W.S.W.; Hassan, M.A.; Ghani, S.A.C.; Buyong, Z. A review of hydroxyapatite-based coating techniques: Sol-gel and electrochemical depositions on biocompatible metals. J. Mech. Behav. Biomed. Mater. 2016, 57, 95-108. [CrossRef] 
26. Harun, W.S.W.; Asri, R.I.M.; Alias, J.; Zulkifli, F.H.; Kadirgama, K.; Ghani, S.A.C.; Shariffuddin, J.H.M. A comprehensive review of hydroxyapatite-based coatings adhesion on metallic biomaterials. Ceram. Int. 2018, 44, 1250-1268. [CrossRef]

27. Bral, A.; Mommaerts, M.Y. In vivo biofunctionalization of titanium patient-specific implants with nano hydroxyapatite and other nano calcium phosphate coatings: A systematic review. J. Cranio-Maxillofac. Surg. 2016, 44, 400-412. [CrossRef]

28. Supernak-Marczewska, M.; Ossowska, A.; Strakowska, P.; Zieliński, A. Nanotubular oxide layers and hydroxyapatite coatings on porous titanium alloy Ti13Nb13Zr. Adv. Mater. Sci. 2018, 18, 17-23. [CrossRef]

29. Bartmanski, M.; Cieslik, B.; Glodowska, J.; Kalka, P.; Pawlowski, L.; Pieper, M.; Zielinski, A. Electrophoretic deposition (EPD) of nanohydroxyapatite-Nanosilver coatings on Ti13Zr13Nb alloy. Ceram. Int. 2017, 43, 11820-11829. [CrossRef]

30. Li, D.; Li, K.; Shan, H. Improving biocompatibility of titanium alloy scaffolds by calcium incorporated silicalite-1 coatings. Inorg. Chem. Commun. 2019, 102, 61-65. [CrossRef]

31. Karimi, N.; Kharaziha, M.; Raeissi, K. Electrophoretic deposition of chitosan reinforced graphene oxide-hydroxyapatite on the anodized titanium to improve biological and electrochemical characteristics. Mater. Sci. Eng. C 2019, 98, 140-152. [CrossRef] [PubMed]

32. Fathyunes, L.; Khalil-Allafi, J.; Moosavifar, M. Development of graphene oxide/calcium phosphate coating by pulse electrodeposition on anodized titanium: Biocorrosion and mechanical behavior. J. Mech. Behav. Biomed. Mater. 2019, 90, 575-586. [CrossRef]

33. Szklarska, M.; Dercz, G.; Simka, W.; Łosiewicz, B. Ac impedance study on the interfacial properties of passivated Ti13Zr13Nb alloy in physiological saline solution. Surf. Interface Anal. 2014, 46, 698-701. [CrossRef]

34. Pradhan, D.; Wren, A.W.; Misture, S.T.; Mellott, N.P. Investigating the structure and biocompatibility of niobium and titanium oxides as coatings for orthopedic metallic implants. Mater. Sci. Eng. C 2016, 58, 918-926. [CrossRef] [PubMed]

35. Gao, A.; Hang, R.; Bai, L.; Tang, B.; Chu, P.K. Electrochemical surface engineering of titanium-based alloys for biomedical application. Electrochim. Acta 2018, 271, 699-718. [CrossRef]

36. Aniołek, K.; Kupka, M.; Barylski, A. Sliding wear resistance of oxide layers formed on a titanium surface during thermal oxidation. Wear 2016, 356-357, 23-29. [CrossRef]

37. Khodaei, M.; Kelishadi, S.H. The effect of different oxidizing ions on hydrogen peroxide treatment of titanium dental implant. Surf. Coat. Technol. 2018, 353, 158-162. [CrossRef]

38. Łęcka, K.M.; Gąsiorek, J.; Mazur-Nowacka, A.; Szczygieł, B.; Antończak, A.J. Adhesion and corrosion resistance of laser-oxidized titanium in potential biomedical application. Surf. Coat. Technol. 2019, 366, 179-189. [CrossRef]

39. Lin, D.J.; Fuh, L.J.; Chen, C.Y.; Chen, W.C.; Lin, J.H.C.; Chen, C.C. Rapid nano-scale surface modification on micro-arc oxidation coated titanium by microwave-assisted hydrothermal process. Mater. Sci. Eng. C 2019, 95, 236-247. [CrossRef]

40. He, X.; Zhang, X.; Wang, X.; Qin, L. Review of Antibacterial Activity of Titanium-Based Implants' Surfaces Fabricated by Micro-Arc Oxidation. Coatings 2017, 7, 45. [CrossRef]

41. Lim, S.-G.; Choe, H.-C. Bioactive apatite formation on PEO-treated Ti-6Al-4V alloy after 3rd anodic titanium oxidation. Appl. Surf. Sci. 2019, 484, 365-373. [CrossRef]

42. Cordeiro, J.M.; Nagay, B.E.; Ribeiro, A.L.R.; da Cruz, N.C.; Rangel, E.C.; Fais, L.M.G.; Vaz, L.G.; Barão, V.A.R. Functionalization of an experimental Ti-Nb-Zr-Ta alloy with a biomimetic coating produced by plasma electrolytic oxidation. J. Alloys Compd. 2019, 770, 1038-1048. [CrossRef]

43. Li, Y.; Wang, W.; Liu, H.; Lei, J.; Zhang, J.; Zhou, H.; Qi, M. Formation and in vitro/in vivo performance of "cortex-like" micro/nanostructured $\mathrm{TiO}_{2}$ coatings on titanium by micro-arc oxidation. Mater. Sci. Eng. C 2018, 87, 90-103. [CrossRef]

44. Wu, B.; Xiong, S.; Guo, Y.; Chen, Y.; Huang, P.; Yang, B. Tooth-colored bioactive titanium alloy prepared with anodic oxidation method for dental implant application. Mater. Lett. 2019, 248, 134-137. [CrossRef]

45. Ossowska, A.; Sobieszczyk, S.; Supernak, M.; Zielinski, A. Morphology and properties of nanotubular oxide layer on the "Ti-13Zr-13Nb" alloy. Surf. Coat. Technol. 2014, 258, 1239-1248. [CrossRef] 
46. Li, T.; Gulati, K.; Wang, N.; Zhang, Z.; Ivanovski, S. Understanding and augmenting the stability of therapeutic nanotubes on anodized titanium implants. Mater. Sci. Eng. C 2018, 88, 182-195. [CrossRef]

47. Ossowska, A.; Beutner, R.; Scharnweber, D.; Zieliński, A. Properties of composite oxide layers on the Ti13Nb13Zr alloy. Surf. Eng. 2017, 33, 841-848. [CrossRef]

48. Wang, G.; Wan, Y.; Ren, B.; Liu, Z. Bioactivity of micropatterned $\mathrm{TiO}_{2}$ nanotubes fabricated by micro-milling and anodic oxidation. Mater. Sci. Eng. C 2019, 95, 114-121. [CrossRef]

49. Roy, P.; Berger, S.; Schmuki, P. $\mathrm{TiO}_{2}$ Nanotubes: Synthesis and applications. Angew. Chem. Int. Ed. 2011, 50, 2904-2939. [CrossRef]

50. Beranek, R.; Hildebrand, H.; Schmuki, P. Self-organized porous titanium oxide prepared in $\mathrm{H}_{2} \mathrm{SO}_{4} / \mathrm{HF}$ electrolytes. Electrochem. Solid State Lett. 2003, 6, B12-B14. [CrossRef]

51. Valota, A.T.; LeClere, D.J.; Skeldon, P.; Curioni, M.; Hashimoto, T.; Berger, S.; Kunze, J.; Schmuki, P.; Thompson, G.E. Influence of water content on nanotubular anodic titania formed in fluoride/glycerolelectrolytes. Electrochim. Acta 2009, 54, 4321-4327. [CrossRef]

52. Albu, S.P.; Ghicov, A.; Aldabergenova, S.; Drechsel, P.; Le Clere, D.; Thompson, G.E.; Macak, J.M.; Schmuki, P. Formation of double-walled $\mathrm{TiO}_{2}$ nanotubes and robust anatase membranes. Adv. Mater. 2008, 20, 4135-4139.

53. Habazaki, H.; Fushimi, K.; Shimizu, K.; Skeldon, P.; Thompson, G.E. Fast migration of fluoride ions in growing anodic titanium oxide. Electrochem. Commun. 2007, 9, 1222-1227. [CrossRef]

54. Berger, S.; Kunze, J.; Schmuki, P.; Valota, A.T.; LeClere, D.J.; Skeldon, P.; Thompson, G.E. Influence of water content on the growth of anodic $\mathrm{TiO}_{2}$ nanotubes in fluoride-containing ethylene glycol electrolytes. J. Electrochem. Soc. 2010, 157. [CrossRef]

55. Majchrowicz, A.; Roguska, A.; Pisarek, M.; Lewandowska, M. Tailoring the morphology of nanotubular oxide layers on Ti-24Nb-4Zr-8Sn $\beta$-phase titanium alloy. Thin Solid Films 2019, 679, 15-21. [CrossRef]

56. Huang, J.; Zhang, X.; Yan, W.; Chen, Z.; Shuai, X.; Wang, A.; Wang, Y. Nanotubular topography enhances the bioactivity of titanium implants. Nanomedicine 2017, 13, 1913-1923. [CrossRef]

57. Pruchova, E.; Kosova, M.; Fojt, J.; Jarolimova, P.; Jablonska, E.; Hybasek, V.; Joska, L. A two-phase gradual silver release mechanism from a nanostructured TiAlV surface as a possible antibacterial modification in implants. Bioelectrochemistry 2019, 127, 26-34. [CrossRef]

58. Oliveira, W.F.; Arruda, I.R.S.; Silva, G.M.M.; Machado, G.; Coelho, L.C.B.B.; Correia, M.T.S. Functionalization of titanium dioxide nanotubes with biomolecules for biomedical applications. Mater. Sci. Eng. C 2017, 81, 597-606. [CrossRef]

59. Zhou, J.; Frank, M.A.; Yang, Y.; Boccaccini, A.R.; Virtanen, S. A novel local drug delivery system: Superhydrophobic titanium oxide nanotube arrays serve as the drug reservoir and ultrasonication functions as the drug release trigger. Mater. Sci. Eng. C 2018, 82, 277-283. [CrossRef]

60. Wu, H.; Xie, L.; Zhang, R.; Tian, Y.; Liu, S.; He, M.; Huang, C.; Tian, W. A novel method to fabricate organic-free superhydrophobic surface on titanium substrates by removal of surface hydroxyl groups. Appl. Surf. Sci. 2019, 479, 1089-1097. [CrossRef]

61. Vilardella, A.M.; Cinca, N.; Garcia-Giralt, N.; Müller, C.; Dosta, S.; Sarret, M.; Cano, I.G.; Nogués, X.; Guilemany, J.M. In-vitro study of hierarchical structures: Anodic oxidation and alkaline treatments onto highly rough titanium cold gas spray coatings for biomedical applications. Mater. Sci. Eng. C 2018, 91, 589-596. [CrossRef] [PubMed]

62. Esmaeilnejad, A.; Mahmoudi, P.; Zamanian, A.; Mozafari, M. Synthesis of titanium oxide nanotubes and their decoration by MnO nanoparticles for biomedical applications. Ceram. Int. 2019, 45, 19275-19282. [CrossRef]

63. Veronesi, F.; Giavaresi, G.; Fini, M.; Longo, G.; Longo, G.; Ioannidu, C.A.; Scotto d'Abusco, A.; Superti, F.; Panzini, G.; Misiano, C.; et al. Osseointegration is improved by coating titanium implants with a nanostructured thin film with titanium carbide and titanium oxides clustered around graphitic carbon. Mater. Sci. Eng. C 2017, 70, 264-271. [CrossRef] [PubMed]

64. Berbel, L.O.; Bonczek, E.P.; Karousis, I.K.; Kotsakis, G.A.; Costa, I. Determinants of corrosion resistance of Ti-6Al-4V alloy dental implants in an In Vitro model of peri-implant inflammation. PLoS ONE 2019. [CrossRef]

65. Van Gilsa, S.; Masta, P.; Stijnsb, E.; Terryna, H. Colour properties of barrier anodic oxide films on aluminium and titanium studied with total reflectance and spectroscopic ellipsometry. Surf. Coat. Technol. 2004, 185, 303-310. [CrossRef] 
66. Yan, X.; Chen, X. Titanium dioxide nanomaterials. In Encyclopedia of Inorganic and Bioinorganic Chemistry; John Wiley \& Sons, Ltd.: New York, NY, USA, 2015.

67. Ekoi, E.J.; Gowen, A.; Dorrepaal, R.; Dowling, D.P. Characterisation of titanium oxide layers using Raman spectroscopy and optical profilometry: Influence of oxide properties. Results Phys. 2019, 12, 1574-1585. [CrossRef]

68. Gajović, A.; Friščić, I.; Plodinec, M.; Iveković, D. High temperature Raman spectroscopy of titanate nanotubes. J. Mol. Struct. 2009, 924-926, 183-191. [CrossRef]

69. Bavykin, D.V.; Walsh, F.C. Titanate and titania nanotubes: Synthesis, properties and applications. RSC Nanosci. Nanotechnol. 2010, 12, 12. [CrossRef]

70. Han, B.; Nezhad, E.Z.; Musharavati, F.; Jaber, F.; Bae, S. Tribo-Mechanical Properties and Corrosion Behavior Investigation of Anodized Ti-V Alloy. Coatings 2018, 8, 459. [CrossRef]

71. Kodama, A.; Bauer, S.; Komatsu, A.; Asoh, H.; Ono, S.; Schmuki, P. Bioactivation of titanium surfaces using coatings of $\mathrm{TiO}_{2}$ nanotubes rapidly pre-loaded with synthetic hydroxyapatite. Acta Biomater. 2009, 5, 2322-2330. [CrossRef]

72. Mazare, A.; Totea, G.; Burnei, C.; Schmuki, P.; Demetrescu, I.; Ionita, D. Corrosion, antibacterial activity and haemocompatibility of $\mathrm{TiO}_{2}$ nanotubes as a function of their annealing temperature. Corros. Sci. 2016, 103, 215-222. [CrossRef]

73. Hryniewicz, T.; Rokosz, K.; Valíček, J.; Rokicki, R. Effect of magnetoelectropolishing on nanohardness and Young's modulus of titanium biomaterial. Mater. Lett. 2012, 83, 69-72. [CrossRef]

74. Ficher-Cripps, A.C. Critical Review of Analysis and Interpretation of nanoindentation test data. Surf. Coat. Technol. 2006, 200, 4153-4165. [CrossRef]

75. Tuck, J.R.; Korsunsky, A.M.; Bhat, D.G.; Bull, S.J. Indentation hardness evaluation of cathodic arc deposited thin hard coatings. Surf. Coat. Technol. 2001, 139, 63-74. [CrossRef]

76. Jiménez-Piquéa, E.; Gaillardb, Y.; Anglada, M. Instrumented indentation of layered ceramic materials. Key Eng. Mater. 2007, 333, 107-116. [CrossRef]

77. Hirvonen, J.K. Ion Implantation; Academic Press: New York, NY, USA, 1980.

78. Heise, S.; Höhlinger, M.; Hernandez, Y.T.; Palacio, J.J.P.; Ortiz, J.A.R.; Wagener, V.; Virtanen, S.; Boccaccini, A.R. Electrophoretic deposition and characterization of chitosan/bioactive glass composite coatings on $\mathrm{Mg}$ alloy substrates. Electrochim. Acta 2017, 232, 456-464. [CrossRef]

79. Ion, R.; Stoian, A.B.; Dumitriu, C.; Grigorescu, S.; Mazare, A.; Cimpean, A.; Demetrescu, I.; Schmuki, P. Nanochannels formed on TiZr alloy improvebiological response. Acta Biomater. 2015, 24, 370-377. [CrossRef]

80. Ammar, Y.; Swailes, D.C.; Bridgens, B.N.; Chen, J. Influence of surface roughness on the initial formation of biofilm. Surf. Coat. Technol. 2015, 284, 410-416. [CrossRef]

81. Saji, V.S.; Choe, H.C.; Brantley, W.A. An electrochemical study on self-ordered nanoporous and nanotubular oxide on Ti-35Nb-5Ta-7Zr alloy for biomedical applications. Acta Biomater. 2009, 5, 2303-2310. [CrossRef]

82. Mazare, A.; Dilea, M.; Ionita, D.; Demetrescu, I. Electrochemical behaviour insimulated body fluid of $\mathrm{TiO}_{2}$ nanotubes on TiAlNb alloy elaborated in variousanodizing electrolyte. Surf. Interface Anal. 2014, 46, 186-192. [CrossRef]

83. Lorenzetti, M.; Dogsa, I.; Stosicki, T.; Stopar, D.; Kalin, M.; Kobe, S.; Novak, S. The influence of surface modification on bacterial adhesion to titanium-based substrates. ACS Appl. Mater. Interfaces 2015, 7, 1644-1651. [CrossRef]

84. Yoda, I.; Koseki, H.; Tomita, M.; Shida, T.; Horiuchi, H.; Sakoda, H.; Osaki, M. Effect of surface roughness of biomaterials on Staphylococcus epidermidis adhesion. BMC Microbiol. 2014, 14, 234. [CrossRef] [PubMed]

85. Cao, Y.; Su, B.; Chinnaraj, S.; Jana, S.; Bowen, L.; Charlton, S.; Duan, P.; Jakubovics, N.S.; Chen, J. Nanostructured titanium surfaces exhibit recalcitrance towards Staphylococcus epidermidis biofilm formation. Sci. Rep. 2018, 8, 1071. [CrossRef]

86. Ercan, B.; Kummer, K.M.; Tarquinio, K.M.; Webster, T.J. Decreased Staphylococcus aureus biofilm growth on anodized nanotubular titanium and the effect of electrical stimulation. Acta Biomater. 2011, 7, 3003-3012. [CrossRef] [PubMed]

87. Simi, V.S.; Rajendran, N. Influence of tunable diameter on the electrochemical behavior and antibacterial activity of titania nanotube arrays for biomedical applications. Mater. Charact. 2017, 129, 67-79. [CrossRef]

88. Chouirfa, H.; Bouloussa, H.; Migonney, V.; Falentin-Daudré, C. Review of titanium surface modification techniques and coatings for antibacterial applications. Acta Biomater. 2019, 83, 37-54. [CrossRef] 
89. Ahmed, W.; Zhai, Z.; Gao, C. Adaptive antibacterial biomaterial surfaces and their applications. Mater. Today Bio 2019, 2, 100017. [CrossRef]

90. Zhao, L.; Wang, H.; Huo, K.; Zhang, X.; Wang, W.; Zhang, Y.; Wu, Z.; Chu, P.K. The osteogenic activity of strontium loaded titania nanotube arrays on titanium substrates. Biomaterials 2013, 34, 19-29. [CrossRef]

(C) 2020 by the authors. Licensee MDPI, Basel, Switzerland. This article is an open access article distributed under the terms and conditions of the Creative Commons Attribution (CC BY) license (http://creativecommons.org/licenses/by/4.0/). 